\title{
RONGSOKAN DIMANFAATKAN SEBAGAI MEDIA UNTUK MENGHASILKAN BATIK KREATIF DENGAN TEKNIK CAP
}

\author{
Nopria Martin ${ }^{1 *}$, Sri Wiratma ${ }^{2 *}$ \\ Program Studi Pendidikan Seni Rupa Jurusan Seni Rupa Fakultas Bahasa dan Seni \\ Universitas Negeri Medan \\ Jl. Willem Iskandar Pasar V Medan Estate, Kec, Percut Sei Tuan, Kab. Deli Serdang, Kode Pos 20371 \\ Sumatera Utara. Indonesia \\ Email:nopriamartin18@gmail.com,sriwiratma@unimed.ac.id
}

\begin{abstract}
Abstrak
Penelitian ini bertujuan untuk mengetahui proses pembuatan batik kreatif teknik cap dengan media rongsokan, serta mengetahui hasil akhir dari proses pembuatan batik kreatif teknik cap dengan media rongsokan". Metode penelitian yang digunakan oleh peneliti dalam pengumpulan data menggunakan metode kualitatif dengan pendekatan deskriptif. Penelitian ini menggunakan metode deskriptif kualitatif. Melakukan penelitian didalam kelas yang sudah tersedia sebagaimana adanya tanpa melakukan perubahan situasi kelas dan jadwal pembelajaran. Perlakuan yang dilaksanakan adalah proses pembuatan batik kreatif dengan teknik cap dan melihat hasil dari karya tersebut. Dari hasil penelitian dapat diketahui proses pembuatan batik kreatif teknik cap dengan media rongsokan di SMP Swasta Salsa Percut Sei Tuan. Teknik pembuatan batik teknik cap deng an media rongsokan atau barang bekas sangat berbeda dengan batik tulis dan batik teknik colet melainkan mencap lang sung pada kain tersebut. Dimana proseny a ialah mencap, mewarna, memblok, melorod, dan (finishing) dan kain batik telah selesai.
\end{abstract}

Kata Kunci: batik cap, rongsokan, proses pembuatan.

\begin{abstract}
This studyaims to knowing the process ofmaking creative batik using stamp techniques with junk media, and knowing the final result of the process ofmaking creative batik using stamp techniques using scrap media". The research method used by researchers in data collection using qualitative methods with a descriptive approach. This study used descriptive qualitative method. Doing research in the classroom that is already available as is without changing the classroom situation and learning schedule. The treatment carried out is the process of making creative batik using stamp techniques and seeing the results of the work. From the research results, it can be seen that the process of making creative batik with stamp techniques using junk media at Salsa Percut Private Middle School in Sei Tuan. The technique of making stamped batik using junk media or used goods is very different from the handwritten batik and the dabbing technique of batik, but it is directly stamped on the cloth. Where the process is stamping, coloring, blocking, melting, and (finishing) and the batik cloth has been finished.
\end{abstract}

Keywords: batik stamp, wreckage, manufacturing proces.

\section{PENDAHULUAN}

Batik merupakan waris an budaya Indonesia. Tentang sejarahnya batik merupakan warisan dari nenek moyang kita yang berkembang sampai sekarang. Jenisnya ada 2 yaitu batik tulis dan batik cap. Tanggapan saya mengenai batik sebagai warisan budaya adalah senang dan bangga karena batik hanya ada di Indonesia, saya bangga untuk memakainya karena dengan memakai batik bisa menaikkan derajat seseorang, batik juga merupakan identitas orang Indonesia, sebagai warga negara Indonesia dengan adany abatik ada yang bisa dibanggakan dari Indonesia sendiri.
Seni budaya merupakan mata pelajaran yang bertujuan untuk mengasah kreativitas peserta didik dalam berkarya seni rupa, salah satunya yaitu kerajinan batik. Batik merupakan kain bergambar yang pembuatanya secara khusus dengan menorehkan malam pada kain, kemudian pengolahannya diproses dengan cara tetentu yang memiliki kekhas an. Teknikdan motif batik tidak hanya bisa diterapkan dikain saja, tetapi juga bisa diterapkan pada berbagai media, seperti kulit, gerabah, bambu, kertas dan kayu.

Namun pembuatan batik dengan teknik cap menggunakan media lain seperti barang bekas atau 
rongs okan s angatjarang sekali dijumpai di masyarakat khususnya dikota Medan sehingga menyebabkan kurangnya pengetahuan dalam pemanfaatan media tersebut. Karena kurang bervariasinya pengetahuan akan pemanfaatan media lain membuat pelajaran menjadi kaku dan monoton sehingga menyebabkan sis wa kurang terampil dalam pembuatan batik kreatif teknik cap dengan menggunakan media ron gsokan atau barang bekas serta menyebabkan kurang terlatihnya kreativitas siswa dalampemanfaatan barang bekas atau rongsokan. Berdasakan pengamatan yang dilakukan dilapangan bahwasanya di sekolah SMP Swasta Salsa juga tidak ditemukan pembuatan batik teknik cap menggunakan media lain khususnya media rongsokan atau barang bekas.

Proses pembuatan batik teknik cap menggunakan media rongsokan atau barang bekas cenderung lebih sederhana dibanding menggunakan media cap yang dibuat oleh tukang maka hasil yang diperoleh akan lebih baik lagi. Teknik pembuatan batik teknik cap dengan media rongsokan atau barang bekas sangat berbeda dengan batik tulis dan batik teknik colet melainkan mencap langsung pada kain tersebut. Dimana prosenya ialah mencap, mewarna, memblok, melorod, dan (finishing). Namun dalam proses mencap s angat diperlukan meja untuk mencap malam ke kain, agar hasil cap yang dilakuakan rapi dan baik, akan tetapi saat memindahkan malam dari kuali ke kain harus hatihati, agar tidak terjadi yang diinginkan oleh pembatik. Selain itu juga saat proses pewarnaannya tidak memerlukan tempat atau wadah yang luas, cukup menggunakan ember atau wadah yang kecil saja.

\section{KAJIAN TEORI}

\section{Pengertian Media}

Ada berbagai media yang dapat digunakan dalam berkarya seni rupa. Media berasal dari kata medium yang berati di tengah. Menurut Haryanto (2007:2) secara umum media terbagi menjadi media desain, yakni pengetahuan tentang bahan, alat, dan proses dalamkomunikasidan jenis produknya; dan media seni rupa yakni mengenai pengetahuan bahan, alat, dan proses atau teknik dalam seni rupa dan jenis produk seni rupa. Pemanfaatan media tidak harus semua dari barang yang dibeli dipasaran, namun bisa juga memfaatkan media-media terbuang seperti "memanfaatkan sampah sebagai bahan baku pembuatan kerajinan” (Azis, 2018).

"Kata "Media" berasal dari bahasa latin yang merupakan bentuk jamak dari "medium", secara harfiah berarti perantara atau pengantar. Association
Gorga : Jurnal Seni Rupa

Volume 09 Nomor 02 Juli-Desember 2020 p-ISSN: 2301-5942 | e-ISSN: 2580-2380

for Education and Communicati on Technology (AECT), men gartikan kata media sebagai segala bentuk dan saluran y ang dipergunakan untuk proses informasi. National Education Association (NEA) mendefinisikan media sebagai segala benda yang dapat dimanipulasikan, dilihat, didengar, dibaca atau dibicarakan beserta instrumen yang dipergunakan untuk kegiatan ters ebut Nurseto (2011:20)".

Media pembelajaran secara umum adalah alat bantu proses belajar mengajar. Segala sesuatu yang dapat dipergunakan untuk merangsang pikiran, perasaan, perhatian dan kemampuan atau ketrampilan pebelajar sehingga dapat mendorong terjadinya proses belajar. Batasan ini cukup luas dan mendalam mencakup pengertian sumber, lingkungan, manusia dan metode yang dimanfaatkan untuk tujuan pembelajaran pelatihan.

Media dalam pengertian seni rupa berbeda dengan media dalam pengertian sebagai pembelajaran. Seperti menurut Gerlach \& Ely (1971:128) mengatakan bahwa media apabila dipahami secara garis besar adalah manusia, materi atau kejadian yang membangun kondisi yang membuat peserta didik mampu memperoleh pengetahuan, keterampilan, atau sikap. Dalam pengertian ini, guru, buku teks, dan lingkungan sekolah merupakan media. Secara lebih khusus, pengertian media dalam proses pembelajaran cenderung diartikan sebagai alat-alat grafis, photografis, atau elektronis untuk menangkap, memproses, dan menyusun kembali informasi visual a tau verbal.

Sedangkan pengertian media menurut Munadi (2008:5) sumber-sumber belajar selain guru inilah yang disebut sebagai penyalur atau penghubung pesan ajar yang diadakan atau diciptakan secara terencana oleh para guru atau pendidik, biasanya sebagai media pembelajaran.

Jadi dapat disimpulkan bahwa media adalah sarana y ang berupa bahan, alat dan teknik dalamberkarya seni rupa. Dalam kaitanya dengan karya seni membatik, maka media dalam berkarya batik adalah s egala sarana yang dapat digunakan dalam berkarya batik.

\section{Pengertian Pewarnaan Alami}

Menurut Hardianingsih (2015:03) Barang bekas dapat dimanfaatkan dalam mengajar karena di sekitar kita banyak sekali terdapat barang bekas yang tidak terpakai. Namun, barang itu masih dapat kita gunakan lagi, di antaranya kita ubah fungsi barang bekas itu sebagai media pembelajaran. 


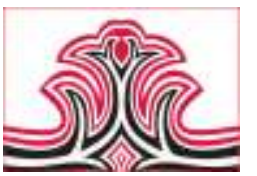

Rongsokan biasa disebut oleh masyarakat sekitar dengan barang bekas dimana menurut:

Nilawati (2010:3) Barang bekas adalah sampah, biasanya benda tersebut langsung dibuang seperti pelastik bekas, kaleng bekas, kain perca dapat kita jumpai dimana-mana. Benda-benda tersebut dapat dimanfaatkan menjadi sebuah karya yang mempunyai nilai estetis dan nilai ekonomis. Barang bekas adalah barang-barang sisa pakai yang sudah tidak digunakan lagi. Keberadaan barang bekas yang sudah tidak terpakai lagi sangat mudah kita temukan dilingkungan sekitaran kita. Berdasarkan sifatnyabarang bekas dapat dikategorikan menjadi barang bekas organik dan barang bekas anorganik.

Rongsokan dimaksudkan semua barang yang telah tidak dipergunakan atau tidak dapat dipakai lagi atau dapat dikatakan sebagai barang yang sudah diambil bagian utamanya (Iskandar, 2006:2). Barang bekas apabila dimanfaatkan sebagai bahan untuk berkarya seni rupa memiliki nilai estetis dan ekonomis sehingga untuk menciptakan karya seni rupa tanpa harus membeli. Barang bekas adalah salah satu alternative yang dapat didayagunakan dan dimanfaatkan sebagai media berkarya seni rupa yang dijangkau untuk memperolehnya.

Dari beberapa pendapat diatas dapat disimpulkan bahwa barang bekas adalah benda yang bagian utamanya sudah diambil/digunakan, jadi barang bekas bisa dimanfaatkan sebagai media pembelajaran dalam berkarya seni rupa selain mudah didapat barang bekas juga memiliki nilai yang estetis dan ekonomis .

\section{METODE PENELITIAN}

Metode penelitian yang dipakai pada penelitian ini adalah Penggunaan metode yang tepat akan memberikan hasily ang baik akan tercapai tujuan untuk menjawab hipotesis yang telah di rumuskan. Oleh karena itu, metode penelitian memegang peranan yang sangat penting dalams ebuah penelitian. Hal ini sejalan dengan pernyataan yang mengatakan bahwa "Metode penelitian merupakan struktur yang sangat penting karena berhasil tidaknya, atau pun tinggi rendahnya kualitas hasil penelitian sangat ditentukan oleh ketepatan dalam memilih metode penelitian.

Metode penelitian yang digunakan oleh peneliti dalam pengumpulan data menggunakan metode kualitatif dengan pendekatan deskriptif, sebagaimana yang diungkapkan oleh Sugiono adalah metode kualitatif untuk mendapatkan data yang mendalam, suatu data yang mengandung makna. Metode kualitatif secara
Gorga : Jurnal Seni Rupa

Volume 09 Nomor 02 Juli-Desember 2020 p-ISSN: 2301-5942 | e-ISSN: 2580-2380

signifikan dapat mempengaruhi subtansi penelitian. Artinya bahwa metode kualitatif menyajikan secara langsung hakikat hubungan antara peneliti dengan informan. (Sugiyono 2015:68).

\section{HASIL DAN PEMBAHAS AN}

\section{Hasil}

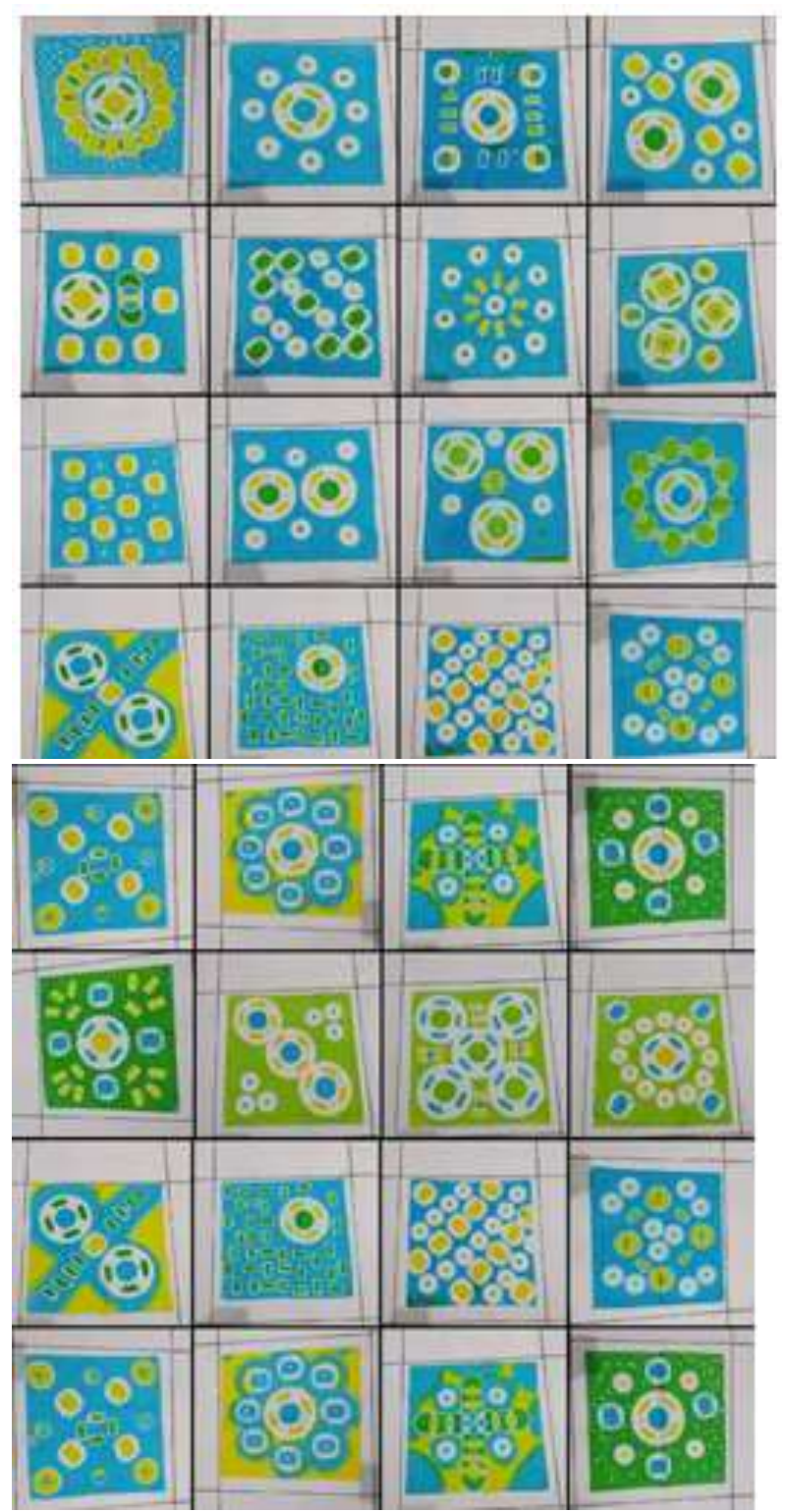




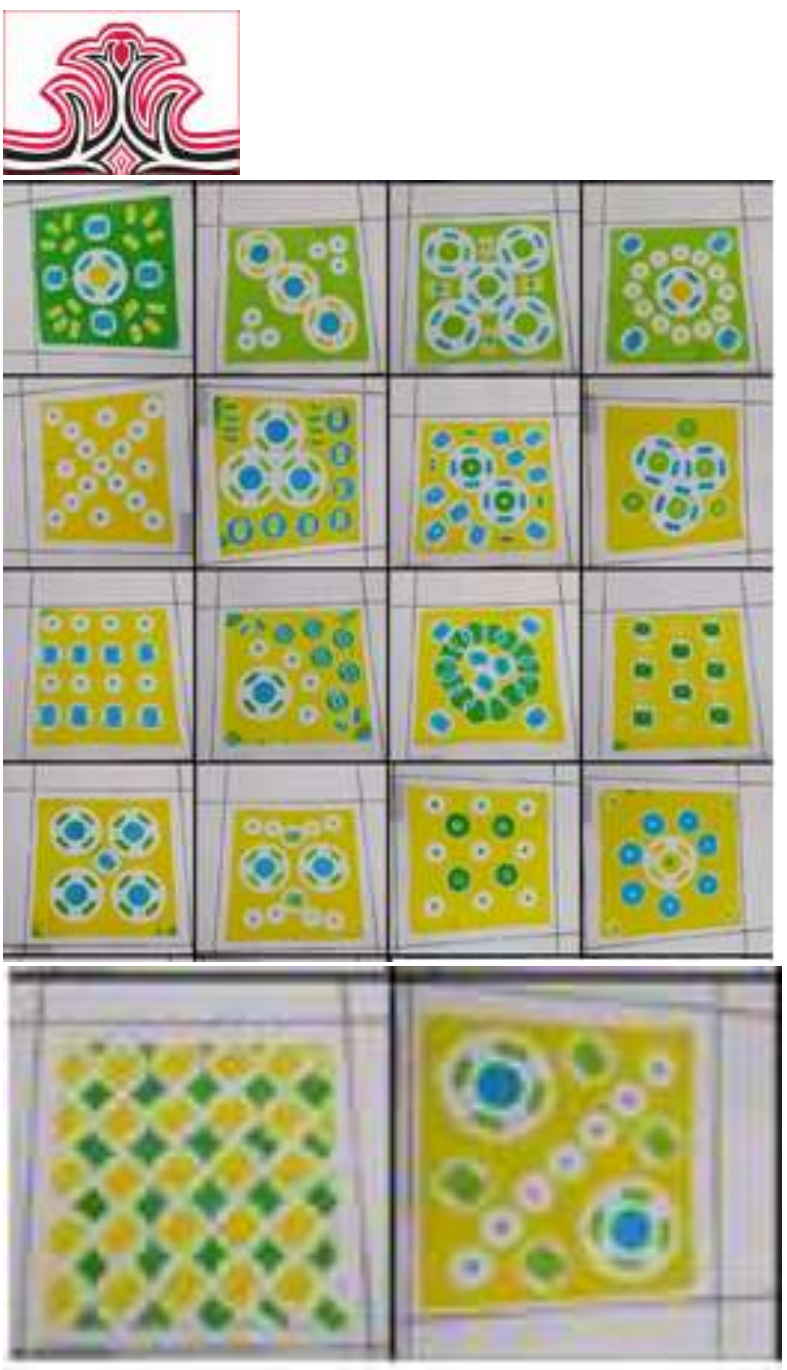

Gambar 1. Hasil Karya Siswa (Martin, 2020)

\section{Pembahasan}

Pada indikator Kreativitas, batik ini sudah bagus dan baik sekali, karena pada kegiatan pemilihan media cap rongs okan sudah pas dan tata peletakan media tersebut sudah baik, sehingga batik ters ebut dapat terlihat indah dan baik sekali, begitu juga dengan pemilihan wama yang ditorehkan ke motif tersebut. Untuk indikator Komposisi, Batik ini berbentuk persegi dengan ukuran 30 x $30 \mathrm{~cm}$ dan komposisi pada batik ini sudah terlihat bagus dan sesuai dengan media yang digunakan.. Pada indikatot Kerapian, Pada batik ini sudah terlihat sangat rapi, karena batik tersebut dari segi komposisi dan kreativitas sudah baik sekali. Dan indikator Finishing Touch, Pada batik ini sudah s angat baik untuk sentuhan akhirnya sehingga batik ini memiliki nilai rata-rat untuk finishing touchnya dari tim penilai adalah 90,3.

Pada indikator Kreativitas, batik ini sudah bagus dan baik sekali, karena pada kegiatan pemilihan media cap rongs okan sudah pas dan tata peletakan media tersebut sudah baik, sehingga batik ters ebut dapat terlihat indah dan baik sekali, begitu juga dengan pemilihan wama yang ditorehkan ke motif tersebut. Untuk indikator Komposisi, Batik ini berbentuk persegi dengan ukuran 30 x $30 \mathrm{~cm}$ dan komposisi pada batikini sudah terlihat
Gorga : Jurnal Seni Rupa

Volume 09 Nomor 02 Juli-Desember 2020 p-ISSN: 2301-5942 | e-ISSN: 2580-2380

bagus dan sesuai dengan media yang digunakan.. Pada indikatot Kerapian, Pada batik ini sudah terlihat sangat rapi, karena batik tersebut dari segi komposisi dan kreativitas sudah baik sekali. Dan indikator Finishing Touch, Pada batik ini sudah sangat baik untuk sentuhan akhirnya sehingga batik ini memiliki nilai rata-rat untuk finishing touchnya dari tim penilai adalah 91,3 .

Pada indikator Kreativitas, batik ini sudah bagus dan baik sekali, karena pada kegiatan pemilihan media cap rongsokan sudah pas dan tata peletakan media tersebut sudah baik, sehing ga batik ters ebut dapat terlihat indah dan baik sekali, begitu juga dengan pemilihan wama yang ditorehkan ke motif tersebut. Untuk indikator Komposisi, Batik ini berbentukpersegi dengan ukuran 30 x $30 \mathrm{~cm}$ dan komposisi pada batik ini sudah terlihat bagus dan sesuai dengan media yang digunakan.. Pada indikatot Kerapian, Pada batik ini sudah terlihat sangat rapi, karena batik tersebut dari segi komposisi dan kreativitas sudah baik sekali. Dan indikator Finishing Touch, Pada batik ini sudah sangat baik untuk sentuhan akhirnya sehingga batik ini memiliki nilai rata-rat untuk finishing touchnya dari tim penilai adalah 91,3 .

Pada indikator Kreativitas, batik ini sudah bagus dan baik sekali, karena pada kegiatan pemilihan media cap rongsokan sudah pas dan tata peletakan media tersebut sudah baik, sehing ga batik ters ebut dapat terlihat indah dan baik sekali, begitu juga dengan pemilihan wama yang ditorehkan ke motif tersebut. Untuk indikator Komposisi, Batik ini berbentuk persegi dengan ukuran $30 \times 30 \mathrm{~cm}$ dan komposisi pada batik ini sudah terlihat bagus dan sesuai dengan media yang digunakan.. Pada indikatot Kerapian, Pada batik ini sudah terlihat sangat rapi, karena batik tersebut dari segi komposisi dan kreativitas sudah baik sekali. Dan indikator Finishing Touch, Pada batik ini sudah sangat baik untuk sentuhan akhirnya sehingga batik ini memiliki nilai rata-rat untuk finishing touchnya dari tim penilai adalah 91,3 .

Pada indikator Kreativitas, batik ini sudah bagus dan baik sekali, karena pada kegiatan pemilihan media cap rongsokan sudah pas dan tata peletakan media tersebut sudah baik, sehing ga batik tersebut dapat terlihat indah dan baik sekali, begitu juga dengan pemilihan wama yang ditorehkan ke motif tersebut. Untuk indikator Komposisi, Batik ini berbentuk persegi dengan ukuran $30 \times 30 \mathrm{~cm}$ dan komposisi pada batik ini sudah terlihat bagus dan sesuai dengan media yang digunakan.. Pada indikatot Kerapian, Pada batik ini sudah terlihat sangat rapi, karena batik tersebut dari segi komposisi dan kreativitas sudah baik sekali. Dan indikator Finishing Touch, Pada batik ini sudah sangat baik untuk sentuhan 
akhirnya sehingga batik ini memiliki nilai rata-rat untuk finishing touchnya dari tim penilai adalah 90 .

Pada indikator Kreativitas, batik ini sudah baik, karena pada kegiatan pemilihan media cap rongsokan sudah bagus dan baik, tata peletakannya juga sudah pas, begitu juga dengan pemilihan warna yang ditorehkan ke motif ters ebut. Untuk indikator Komposisi, Batik ini berbentuk persegi dengan ukuran 30 x $30 \mathrm{~cm}$ dan kompos is ipada batik ini sudah terlihat bagus dan sesuai dengan media yang digunakan. Pada indikatot Kerapian, Pada batik ini sedikit terlihat tidak rapi, karena pada batikini masih ada terlihat tetesan malam pada kain. Dan indikator Finishing Touch, Pada batik ini sudah baik untuk s entuhan akhirnya, s ehingga batik ini memiliki nilai rata-rat untuk finishing touchnyadari tim penilai adalah 87 .

Pada indikator Kreativitas, batik ini sudah baik, karena pada kegiatan pemilihan media cap rongs okan sudah bagus dan baik, tata peletakannya juga sudah pas, begitu juga dengan pemilihan warna yang ditorehkan ke motif ters ebut. Untuk indikator Komposisi, Batik ini berbentuk persegi dengan ukuran 30 x $30 \mathrm{~cm}$ dan kompos is i pada batik ini sudah terlihat bagus dan sesuai dengan media yang digunakan. Pada indikatot Kerapian, Pada batik ini sedikit terlihat tidak rapi, karena pada batik ini masih ada terlihat tetesan wama lain pada kain. Dan indikator Finishing Touch, Pada batik ini sudah baik untuk s entuhan akhirnya, s ehingga batik ini memiliki nilai rata-rat untuk finishing touchnya dari tim penilai adalah 89,6 .

Pada indikator Kreativitas, batik ini sudah bagus dan baik sekali, karena pada kegiatan pemilihan media cap rongs okan sudah pas dan tata peletakan media tersebut sudah baik, sehing ga batik ters ebut dapat terlihat indah dan baik sekali, begitu juga dengan pemilihan wama yang ditorehkan ke motif tersebut. Untuk indikator Komposisi, Batik ini berbentuk persegi dengan ukuran 30 x $30 \mathrm{~cm}$ dan komposisi pada batikini sudah terlihat bagus dan sesuai dengan media yang digunakan.. Pada indikatot Kerapian, Pada batik ini sudah terlihat sangat rapi, karena batik tersebut dari segi komposisi dan kreativitas sudah baik sekali. Dan indikator Finishing Touch, Pada batikini sudah s angat baik untuk sentuhan akhirnya sehingga batik ini memiliki nilai rata-rat untuk finishing touchnya dari tim penilai adalah 90 .

Pada indikator Kreativitas, batik ini sudah baik, karena pada kegiatan pemilihan media cap rongs okan sudah bagus dan baik, tata peletakannya juga sudah pas, begitu juga dengan pemilihan warna yang ditorehkan ke motif ters ebut. Untuk indikator Komposisi, Batik ini
Gorga : Jurnal Seni Rupa

Volume 09 Nomor 02 Juli-Desember 2020

p-ISSN: 2301-5942 | e-ISSN: 2580-2380

berbentuk persegi dengan ukuran 30 x $30 \mathrm{~cm}$ dan komposisi pada batik ini sudah terlihat bagus dan sesuai dengan media yang digunakan. Pada indikatot Kerapian, Pada batik ini sedikit terlihat tidak rapi, karena pada batik ini masih ada terlihat tetesan wama lain dan malam pada kain. Dan indikator Finishing Touch, Pada batik ini sudah baik untuk sentuhan akhirnya, sehingga batik ini memiliki nilai rata-rat untukfinishing touchnya dari tim penilai adalah 88,6.

Pada indikator Kreativitas, batik ini sudah bagus dan baik sekali, karena pada kegiatan pemilihan media cap rongsokan sudah pas dan tata peletakan media tersebut sudah baik, sehing ga batik ters ebut dapat terlihat indah dan baik sekali, begitu juga dengan pemilihan wama yang ditorehkan ke motif tersebut. Untuk indikator Komposisi, Batik ini berbentuk persegi dengan ukuran $30 \times 30 \mathrm{~cm}$ dan kompos is i pada batikini sudah terlihat bagus dan sesuai den gan media yang digunakan.. Pada indikatot Kerapian, Pada batik ini sudah terlihat sangat rapi, karena batik tersebut dari segi komposisi dan kreativitas sudah baik sekali. Dan indikator Finishing Touch, Padabatikini sudah san gat baik untuk sentuhan akhirnya sehingga batik ini memiliki nilai rata-rat untuk finishing touchnya dari tim penilai adalah 91 .

Pada indikator Kreativitas, batik ini sudah baik, karena pada kegiatan pemilihan media cap rongsokan sudah bagus dan baik, tata peletakannya juga sudah pas, begitu juga dengan pemilihan warna yang ditorehkan ke motif ters ebut. Untuk indikator Komposisi, Batikini berbentuk persegi dengan ukuran 30 x $30 \mathrm{~cm}$ dan kompos is i pada batik ini sudah terlihat bagus dan sesuai dengan media yang digunakan. Pada indikatot Kerapian, Pada batik ini sedikit terlihat tidak rapi, karena pada batik ini masih ada terlihat tetesan wama lain pada kain. Dan indikator Finishing Touch, Pada batik ini sudah baik untuk sentuhan akhirnya, sehingga batik ini memiliki nilai rata-rat untuk finishing touchnya dari tim penilai adalah 89,6 .

Pada indikator Kreativitas, batik ini sudah bagus dan baik sekali, karena pada kegiatan pemilihan media cap rongsokan sudah pas dan tata peletakan media tersebut sudah baik, sehing ga batik ters ebut dapat terlihat indah dan baik sekali, begitu juga dengan pemilihan wama yang ditorehkan ke motif tersebut. Untuk indikator Komposisi, Batikini berbentuk persegi dengan ukuran $30 \times 30 \mathrm{~cm}$ dan komposisi pada batikini sudah terlihat bagus dan sesuai dengan media yang digunakan.. Pada indikatot Kerapian, Pada batik ini sudah terlihat sangat rapi, karena batik ters ebut dari segi komposisi dan kreativitas sudah baik sekali. Dan indikator Finishing Touch, Padabatikini sudah sangat baik untuk sentuhan 
akhirnya sehingga batik ini memiliki nilai rata-rat untuk finishing touchnya dari tim penilai adalah 90 .

Pada indikator Kreativitas, batik ini sudah baik, karena pada kegiatan pemilihan media cap rongsokan sudah bagus dan baik, tata peletakannya juga sudah pas, begitu juga dengan pemilihan warna yang ditorehkan ke motif ters ebut. Untuk indikator Komposisi, Batik ini berbentuk persegi dengan ukuran 30 x $30 \mathrm{~cm}$ dan kompos is ipada batik ini sudah terlihat bagus dan sesuai dengan media yang digunakan. Pada indikatot Kerapian, Pada batik ini sedikit terlihat tidak rapi, karena pada batik ini masih ada terlihat tetesan wama lain pada kain. Dan indikator Finishing Touch, Pada batik ini sudah baik untuk s entuhan akhirnya, sehingga batik ini memiliki nilai rata-rat untuk finishing touchnya dari tim penilai adalah 88 .

Pada indikator Kreativitas, batik ini sudah bagus dan baik s ekali, karena pada kegiatan pemilihan media cap rongsokan sudah pas dan tata peletakan media tersebut sudah baik, s ehingga batik ters ebut dapat terlihat indah dan baik sekali, begitu juga dengan pemilihan wama yang ditorehkan ke motif tersebut. Untuk indikator Komposisi, Batikini berbentuk persegi dengan ukuran 30 x $30 \mathrm{~cm}$ dan komposisi pada batikini sudah terlihat bagus dan sesuai dengan media yang digunakan.. Pada indikatot Kerapian, Pada batik ini sudah terlihat sangat rapi, karena batik ters ebut dari segi komposisi dan kreativitas sudah baik sekali. Dan indikator Finishing Touch, Pada batikini sudah s angat baik untuk sentuhan akhirnya sehingga batik ini memiliki nilai rata-rat untuk finishing touchnya dari tim penilai adalah 91 .

Pada indikator Kreativitas, batik ini sudah bagus dan baik sekali, karena pada kegiatan pemilihan media cap rongs okan sudah pas dan tata peletakan media tersebut sudah baik, sehing ga batik ters ebut dapat terlihat indah dan baik sekali, begitu juga dengan pemilihan wama yang ditorehkan ke motif tersebut. Untuk indikator Komposisi, Batikini berbentuk persegi dengan ukuran 30 x $30 \mathrm{~cm}$ dan komposisi pada batikini sudah terlihat bagus dan sesuai dengan media yang digunakan.. Pada indikatot Kerapian, Pada batikini sudah terlihat sangat rapi, karena batik ters ebut dari segi komposisi dan kreativitas sudah baik sekali. Dan indikator Finishing Touch, Padabatikini sudah s angat baik untuk sentuhan akhirnya sehingga batik ini memiliki nilai rata-rat untuk finis hing touchnya dari tim penilai adalah 90,3.

Pada indikator Kreativitas, batik ini sudah bagus dan baik sekali, karena pada kegiatan pemilihan media cap rongs okan sudah pas dan tata peletakan media tersebut sudah baik, sehingga batik ters ebut dapat terlihat indah
Gorga : Jurnal Seni Rupa

Volume 09 Nomor 02 Juli-Desember 2020

p-ISSN: 2301-5942 | e-ISSN: 2580-2380

dan baik sekali, begitu juga dengan pemilihan wama yang ditorehkan ke motif tersebut. Untuk indikator Komposisi, Batikini berbentuk persegi dengan ukuran 30 x $30 \mathrm{~cm}$ dan komposis i pada batik ini sudah terlihat bagus dan sesuai dengan media yang digunakan.. Pada indikatot Kerapian, Pada batik ini sudah terlihat sangat rapi, karena batik tersebut dari segi komposisi dan kreativitas sudah baik sekali. Dan indikator Finishing Touch, Padabatikini sudah san gat baik untuk sentuhan akhirnya sehingga batik ini memiliki nilai rata-rat untukfinis hing touchnya dari tim penilai adalah 90,6.

Pada indikator Kreativitas, batik ini sudah baik, karena pada kegiatan pemilihan media cap rongs okan sudah bagus dan baik, tata peletakannya juga sudah pas, begitu juga dengan pemilihan warna yang ditorehkan ke motif ters ebut. Untuk indikator Komposisi, Batik ini berbentuk persegi dengan ukuran 30 x $30 \mathrm{~cm}$ dan kompos is i pada batik ini sudah terlihat bagus dan sesuai dengan media yang digunakan. Pada indikatot Kerapian, Pada batik ini sedikit terlihat tidak rapi, karena pada batik ini masih ada terlihat tetesan wama lain dan malam pada kain. Dan indikator Finishing Touch, Pada batik ini sudah baik untuk sentuhan akhirnya, sehingga batik ini memiliki nilai rata-rat untuk finishing touchnya dari tim penilai adalah 88 .

Pada indikator Kreativitas, batik ini sudah baik, karena pada kegiatan pemilihan media cap rongsokan sudah bagus dan baik, tata peletakannya juga sudah pas, begitu juga dengan pemilihan warna yang ditorehkan ke motif ters ebut. Untuk indikator Komposisi, Batik ini berbentuk persegi dengan ukuran 30 x $30 \mathrm{~cm}$ dan kompos is i padabatikini sudah terlihat bagus dan sesuai dengan media yang digunakan. Pada indikatot Kerapian, Pada batik ini sedikit terlihat tidak rapi, karena pada batik ini masih ada terlihat tidak rapi tata peletakanya pada kain. Dan indikator Finishing Touch, Pada batik ini sudah baik untuk sentuhan akhirnya, sehingga batik ini memiliki nilai rata-rat untuk finishing touchnya dari tim penilai adalah 87 .

Pada indikator Kreativitas, batik ini sudah bagus dan baik sekali, karena pada kegiatan pemilihan media cap rongsokan sudah pas dan tata peletakan media tersebut sudah baik, sehing ga batik ters ebut dapat terlihat indah dan baik sekali, begitu juga dengan pemilihan wama yang ditorehkan ke motif tersebut. Untuk indikator Komposisi, Batik ini berbentuk persegi dengan ukuran $30 \times 30 \mathrm{~cm}$ dan komposis i pada batikini sudah terlihat bagus dan sesuai dengan media yang digunakan.. Pada indikatot Kerapian, Pada batik ini sudah terlihat sangat rapi, karena batik tersebut dari segi komposisi dan kreativitas sudah baik sekali. Dan indikator Finishing 
Touch, Pada batik ini sudah s angat baik untuk sentuhan akhirnya sehingga batik ini memiliki nilai rata-rat untuk finishing touchnya dari tim penilai adalah 90,6.

Pada indikator Kreativitas, batik ini sudah bagus dan baik sekali, karena pada kegiatan pemilihan media cap rongs okan sudah pas dan tata peletakan media tersebut sudah baik, sehingga batik ters ebut dapat terlihat indah dan baik sekali, begitu juga dengan pemilihan wama yang ditorehkan ke motif tersebut. Untuk indikator Komposisi, Batikini berbentukpersegi dengan ukuran 30 x $30 \mathrm{~cm}$ dan komposisi pada batik ini sudah terlihat bagus dan sesuai dengan media yang digunakan.. Pada indikatot Kerapian, Pada batikini sudah terlihat sangat rapi, karena batik tersebut dari segi komposisi dan kreativitas sudah baik sekali. Dan indikator Finishing Touch, Pada batik ini sudah s angat baik untuk sentuhan akhirnya sehingga batik ini memiliki nilai rata-rat untuk finishing touchnya dari tim penilai adalah 91 .

Pada indikator Kreativitas, batik ini sudah baik, karena pada kegiatan pemilihan media cap rongsokan sudah bagus dan baik, tata peletakannya juga sudah pas, begitu juga dengan pemilihan warna yang ditorehkan ke motif ters ebut. Untukindikator Komposisi, Batik ini berbentuk persegi dengan ukuran 30 x $30 \mathrm{~cm}$ dan kompos is i pada batik ini sudah terlihat bagus dan sesuai dengan media yang digunakan. Pada indikatot Kerapian, Pada batik ini sedikit terlihat tidak rapi, karena pada batik ini masih ada terlihat tidak rapi tata peletakannya pada kain. Dan indikator Finishing Touch, Pada batik ini sudah baik untuk sentuhan akhirnya, sehingga batik ini memiliki nilai rata-rat untuk finishing touchnya dari tim penilai adalah 85,3

Pada indikator Kreativitas, batik ini sudah baik, karena pada kegiatan pemilihan media cap rongsokan sudah bagus dan baik, tata peletakannya juga sudah pas, begitu juga dengan pemilihan warna yang ditorehkan ke motif ters ebut. Untuk indikator Komposisi, Batik ini berbentuk persegi dengan ukuran 30 x $30 \mathrm{~cm}$ dan kompos is i pada batik ini sudah terlihat bagus dan sesuai dengan media yang digunakan. Pada indikatot Kerapian, Pada batik ini sedikit terlihat tidak rapi, karena pada batik ini masih ada terlihat tidak rapi tata peletakan ya pada kain. Dan indikator Finishing Touch, Pada batik ini sudah baik untuk sentuhan akhirnya, sehingga batik ini memiliki nilai rata-rat untuk finishing touchnya dari timpenilai adalah 81 .

Pada indikator Kreativitas, batik ini sudah bagus dan baik sekali, karena pada kegiatan pemilihan media cap rongs okan sudah pas dan tata peletakan media tersebut sudah baik, sehingga batik ters ebut dapat terlihat indah
Gorga : Jurnal Seni Rupa

Volume 09 Nomor 02 Juli-Desember 2020

p-ISSN: 2301-5942 | e-ISSN: 2580-2380

dan baik sekali, begitu juga dengan pemilihan wama yang ditorehkan ke motif tersebut. Untuk indikator Komposisi, Batikini berbentuk persegi dengan ukuran 30 x $30 \mathrm{~cm}$ dan komposis i pada batik ini sudah terlihat bagus dan sesuai dengan media yang digunakan.. Pada indikatot Kerapian, Pada batik ini sudah terlihat sangat rapi, karena batik tersebut dari segi komposisi dan kreativitas sudah baik sekali. Dan indikator Finishing Touch, Padabatikini sudah sangat baik untuk sentuhan akhirnya sehingga batik ini memiliki nilai rata-rat untukfinis hing touchnya dari tim penilai adalah 91,3.

Pada indikator Kreativitas, batik ini sudah baik, karena pada kegiatan pemilihan media cap rongs okan sudah bagus dan baik, tata peletakannya juga sudah pas, begitu juga dengan pemilihan warna yang ditorehkan ke motif ters ebut. Untuk indikator Komposisi, Batik ini berbentuk persegi dengan ukuran 30 x $30 \mathrm{~cm}$ dan kompos is i pada batik ini sudah terlihat bagus dan sesuai dengan media yang digunakan. Pada indikatot Kerapian, Pada batik ini sedikit terlihat tidak rapi, karena pada batik ini masih ada terlihat tidak rapi tata peletakannya pada kain. Dan indikator Finishing Touch, Pada batik ini sudah baik untuk sentuhan akhirnya, sehingga batik ini memiliki nilai rata-rat untukfinishing touchnya dari tim penilai adalah 88,3.

Pada indikator Kreativitas, batik ini sudah baik, karena pada kegiatan pemilihan media cap rongsokan sudah bagus dan baik, tata peletakannya juga sudah pas, begitu juga dengan pemilihan warna yang ditorehkan ke motif ters ebut. Untuk indikator Komposisi, Batik ini berbentuk persegi dengan ukuran 30 x $30 \mathrm{~cm}$ dan kompos isi padabatik ini sudah terlihat bagus dan sesuai dengan media yang digunakan. Pada indikatot Kerapian, Pada batik ini sedikit terlihat tidak rapi, karena pada batik ini masih ada terlihat tidak rapi tata peletakannya dan ada tetesan malam pada kain. Dan indikator Finishing Touch, Pada batik ini sudah baik untuk sentuhan akhirnya, sehingga batik ini memiliki nilai rata-rat untuk finis hing touchnya dari tim penilai adalah 89,6 .

Pada indikator Kreativitas, batikini sudah baik, karena pada kegiatan pemilihan media cap rongsokan sudah bagus dan baik, tata peletakannya juga sudah pas, begitu juga dengan pemilihan warna yang ditorehkan ke motif ters ebut. Untuk indikator Komposisi, Batikini berbentuk persegi dengan ukuran 30 x $30 \mathrm{~cm}$ dan kompos is i padabatik ini sudah terlihat bagus dan sesuai dengan media yang digunakan. Pada indikatot Kerapian, Pada batik ini sedikit terlihat tidak rapi, karena pada batik ini masih ada terlihat tidak rapi tata peletakannya dan ada tetesan malam pada kain. 
Dan indikator Finishing Touch, Pada batik ini sudah baik untuk sentuhan akhirnya, sehingga batik ini memiliki nilai rata-rat untuk finishing touchnya dari tim penilai adalah 89,6 .

Pada indikator Kreativitas, batik ini sudah baik, karena pada kegiatan pemilihan media cap rongs okan sudah bagus dan baik, tata peletakannya juga sudah pas, begitu juga dengan pemilihan warna yang ditorehkan ke motif ters ebut. Untuk indikator Komposisi, Batik ini berbentuk persegi dengan ukuran 30 x $30 \mathrm{~cm}$ dan kompos is i pada batik ini sudah terlihat bagus dan sesuai dengan media yang digunakan. Pada indikatot Kerapian, Pada batik ini sedikit terlihat tidak rapi, karena pada batik ini masih ada terlihat tidak rapi tata peletakannya dan ada tetesan malam pada kain. Dan indikator Finishing Touch, Pada batik ini sudah baik untuk sentuhan akhirnya, sehingga batik ini memiliki nilai rata-rat untuk finis hing touchnya dari tim penilai adalah 86.

Pada indikator Kreativitas, batik ini sudah baik, karena pada kegiatan pemilihan media cap rongs okan sudah bagus dan baik, tata peletakannya juga sudah pas, begitu juga dengan pemilihan warna yang ditorehkan ke motif ters ebut. Untukindikator Komposisi, Batik ini berbentuk persegi dengan ukuran 30 x $30 \mathrm{~cm}$ dan kompos is ipada batik ini sudah terlihat bagus dan sesuai dengan media yang digunakan. Pada indikatot Kerapian, Pada batik ini sedikit terlihat tidak rapi, karena pada batik ini masih ada terlihat tidak rapi tata peletakannya dan ada tetesan malam pada kain. Dan indikator Finishing Touch, Pada batik ini sudah baik untuk sentuhan akhirnya, sehingga batik ini memiliki nilai rata-rat untuk finis hing touchnya dari tim penilai adalah 88

Pada indikator Kreativitas, batik ini sudah bagus dan baik sekali, karena pada kegiatan pemilihan media cap rongsokan sudah pas dan tata peletakan media tersebut sudah baik, sehingga batik ters ebut dapat terlihat indah dan baik sekali, begitu juga dengan pemilihan wama yang ditorehkan ke motif tersebut. Untuk indikator Komposisi, Batikini berbentukpersegi dengan ukuran 30 x $30 \mathrm{~cm}$ dan komposisi pada batikini sudah terlihat bagus dan sesuai dengan media yang digunakan.. Pada indikatot Kerapian, Pada batik ini sudah terlihat sangat rapi, karena batik tersebut dari segi komposisi dan kreativitas sudah baik sekali. Dan indikator Finishing Touch, Pada batik ini sudah s angat baik untuk sentuhan akhirnya sehingga batik ini memiliki nilai rata-rat untuk finishing touchnya dari tim penilai adalah 90.
Gorga : Jurnal Seni Rupa Volume 09 Nomor 02 Juli-Desember 2020 p-ISSN: 2301-5942 | e-ISSN: 2580-2380

Pada indikator Kreativitas, batik ini sudah bagus dan baik sekali, karena pada kegiatan pemilihan media cap rong sokan sudah pas dan tata peletakan media tersebut sudah baik, sehing ga batik ters ebut dapat terlihat indah dan baik sekali, begitu juga dengan pemilihan wama yang ditorehkan ke motif tersebut. Untuk indikator Komposisi, Batikini berbentukpersegi dengan ukuran $30 \times 30 \mathrm{~cm}$ dan komposis i pada batikini sudah terlihat bagus dan sesuai den gan media yang digunakan.. Pada indikatot Kerapian, Pada batik ini sudah terlihat sangat rapi, karena batik tersebut dari segi komposisi dan kreativitas sudah baik sekali. Dan indikator Finishing Touch, Padabatikini sudah san gat baik untuk sentuhan akhirnya sehingga batik ini memiliki nilai rata-rat untuk finishing touchnya dari tim penilai adalah 91.

Pada indikator Kreativitas, batik ini sudah baik, karena pada kegiatan pemilihan media cap rongsokan sudah bagus dan baik, tata peletakannya juga sudah pas, begitu juga dengan pemilihan warna yang ditorehkan ke motif ters ebut. Untuk indikator Komposisi, Batik ini berbentuk persegi dengan ukuran 30 x $30 \mathrm{~cm}$ dan kompos is i pada batik ini sudah terlihat bagus dan sesuai dengan media yang digunakan. Pada indikatot Kerapian, Pada batik ini sedikit terlihat tidak rapi, karena pada batik ini masih ada terlihat tidak rapi tata peletakannya pada kain. Dan indikator Finishing Touch, Pada batik ini sudah baik untuk sentuhan akhirnya, sehingga batik ini memiliki nilai rata-rat untuk finis hing touchnya dari tim penilai adalah 89,6.

Pada indikator Kreativitas, batik ini sudah baik, karena pada kegiatan pemilihan media cap rongsokan sudah bagus dan baik, tata peletakannya juga sudah pas, begitu juga dengan pemilihan warna yang ditorehkan ke motif ters ebut. Untuk indikator Komposisi, Batik ini berbentuk persegi dengan ukuran 30 x $30 \mathrm{~cm}$ dan komposis i padabatikini sudah terlihat bagus dan sesuai dengan media yang digunakan. Pada indikatot Kerapian, Pada batik ini sedikit terlihat tidak rapi, karena pada batik ini mas ih ada terlihat tidak rapi tata peletakannya pada kain. Dan indikator Finishing Touch, Pada batik ini sudah baik untuk sentuhan akhirnya, sehingga batik ini memiliki nilai rata-rat untukfinishing touchnya dari tim penilai adalah 87,3.

Pada indikator Kreativitas, batikini sudah baik, karena pada kegiatan pemilihan media cap rongsokan sudah bagus dan baik, tata peletakannya juga sudah pas, begitu juga dengan pemilihan warna yang ditorehkan ke motif ters ebut. Untuk indikator Komposisi, Batik ini berbentuk persegi dengan ukuran 30 x $30 \mathrm{~cm}$ dan kompos is i padabatikini sudah terlihat bagus dan sesuai dengan media yang digunakan. Pada indikatot 
Kerapian, Pada batik ini sedikit terlihat tidak rapi, karena pada batik ini masih ada terlihat tidak rapi tata peletakannya pada kain. Dan indikator Finishing Touch, Pada batik ini sudah baik untuk sentuhan akhirnya, sehingga batik ini memiliki nilai rata-rat untuk finishing touchnya dari tim penilai adalah 87 .

Pada indikator Kreativitas, batik ini sudah baik, karena pada kegiatan pemilihan media cap rongsokan sudah bagus dan baik, tata peletakannya juga sudah pas, begitu juga dengan pemilihan warna yang ditorehkan ke motif tersebut. Untuk indikator Komposisi, Batik ini berbentuk persegi dengan ukuran 30 x $30 \mathrm{~cm}$ dan komposisi pada batik ini sudah terlihat bagus dan sesuai den gan media yang digunakan. Pada indikatot Kerapian, Padabatik ini sedikit terlihat tidak rapi, karena pada batik ini mas ih ada terlihat tidak rapi tata peletakannya dan ada tetesan malam pada kain. Dan indikator Finishing Touch, Pada batik ini sudah baik untuk sentuhan akhirnya, sehingga batik ini memiliki nilai rata-rat untuk finishing touchnya dari tim penilai adalah 87 .

Pada indikator Kreativitas, batik ini sudah baik, karena pada kegiatan pemilihan media cap rongsokan sudah bagus dan baik, tata peletakannya juga sudah pas, begitu juga dengan pemilihan warna yang ditorehkan ke motif tersebut. Untuk indikator Komposisi, Batik ini berbentuk persegi dengan ukuran 30 x $30 \mathrm{~cm}$ dan kompos isi pada batik ini sudah terlihat bagus dan sesuai dengan media yang digunakan. Pada indikatot Kerapian, Padabatik ini sedikit terlihat tidak rapi, karena pada batik ini mas ih ada terlihat tidak rapi tata peletakannya pada kain. Dan indikator Finishing Touch, Pada batik ini sudah baik untuk sentuhan akhirnya, sehing ga batik ini memiliki nilai rata-rat untukfinishing touchnya dari tim penilai adalah 88

Pada indikator Kreativitas, batik ini sudah bagus dan baik sekali, karena pada kegiatan pemilihan media cap rongs okan sudah pas dan tata peletakan media tersebut sudah baik, s ehingga batik ters ebut dapat terlihat indah dan baik sekali, begitu juga dengan pemilihan wama yang ditorehkan ke motif tersebut. Untuk indikator Komposisi, Batik ini berbentuk persegi dengan ukuran 30 x $30 \mathrm{~cm}$ dan komposisi pada batikini sudah terlihat bagus dan sesuai dengan media yang digunakan.. Pada indikatot Kerapian, Pada batikini sudah terlihat sangat rapi, karena batik tersebut dari segi komposisi dan kreativitas sudah baik sekali. Dan indikator Finishing Touch, Pada batik ini sudah s angat baik untuk sentuhan akhirnya sehingga batik ini memiliki nilai rata-rat untuk finishing touchnya dari tim penilai adalah 90,3.
Gorga : Jurnal Seni Rupa

Volume 09 Nomor 02 Juli-Desember 2020 p-ISSN: 2301-5942 | e-ISSN: 2580-2380

\section{KESIMPULAN DAN SARAN 1.Kesimpulan}

Berdas arkan dari pengelolaan data maka dapat dibuat kesimpulan sebagai berikut: Rongsokan sangat jarang sekali dijumpai di masy arakat khususn ya dikotaMedan sehingga menyebabkan kurang nya pengetahuan dalam pemanfaatan media tersebut. Karena kurang bervariasinya pengetahuan akan pemanfaatan media itu membuat pelajaran menjadi kaku dan monoton sehingga menyebabkan sis wa kurang terampil dalam menggunakan media rongsokan atau barang bekas serta menyebabkan kurang terlatihnya kreativitas siswa dalam pemanfaatan media rongsokan atau barang bekas, Batik cap adalah kain yang cara pembuatan corak dan motifnya dengan menggunakan cap atau semacam stempel yang terbuat dari tembaga. Cap ters ebut menggantikan fungsi canting dalammembatik, dengan cap ini maka satu helai kain batik dapat dis eles aikan dalam waktu sing kat, dari Hasil tersebut yang telah dilakukan peneliti mengetahui bahwa siswa kurang terampil dalam memanfaatkan media rongsokan, khususnya untuk membuat batik kreatif teknik cap dengan media rongs okan.

\section{Saran}

Keseluruhan hasil penelitian yang dilakukan oleh peneliti mengenai Pemanfaatan media rongsokan untuk menghasilkan batik kreatif dengan teknik cap di SMP Swasta Salsa maka penulis memberikan saran-saran sebagai berikut: Bagi para guru sebaiknya sering mengajarkan pembelajaran menggunakan media rongsokan, karena rongsokan selain mudah didapat, ia juga memiliki banyak manfaat. Contohnya membuat batik kreatif teknik cap dengan media rongsokan dan bagi para siswa sebaiknya lebih terampil lagi dalam mengkreasikan dan memanfaatkan rongsokan sebagai media untuk berkreativitas baik di sekolah maupun di rumah.

\section{DAFTAR RUJUKAN}

Azis, A. C. K. (2018). Sampah Anorganik Menjadi Kerajinan Tas pada Kelompok Program Keluarga Harapan (PKH) di Kecamatan Deli Tua. JurnalPengabdian Kepada Masyarakat, 24(2), 689-694.

Gerlach,V.G. dan Ely, D, P. (1971). Teaching and Media. A. Systematic Approach. Englewood Cliffs: Prentice-Hill, Inc.

Hanafi, S, H. (2015). Upaya Meningkatkan Kreativitas Anak Dengan Memanfaatkan Media Barang Bekas di TK Kota Bima. Jurnal Pendidikan dan Pemberdayaan Masyarakay (JPPM), 2(2), 215-225.

Haryanto, H. (2007). Media, Seni Rupa, Desain dan Craft. Semarang: UNNES. 
Is kandar, I. dan Agus, A. (2006). Daur Ulang Sampah. Jakarta: Azka Mulia Media.

Martin, N. (2020). "Hasil Karya Siswa". Hasil Dokumentasi Pribadi: 06 Oktober 2020, SMP Swasta Salsa.

Munadi, Yudhi. (2008). Media Pembelajaran. Jakarta: Gaung Persada Press.

Nilawati, N. dan Sativa, E. (2010). Menyulap Sampah Jadi Krajinan Cantik. Jakarta: Nobel Edumedia. Suarni, Marungkil Pasaribu, dan Amran Rede. 2010. Pemanfaatan Barang Bekas Sebagai Media Pembelajaran Untuk Meningkatkan Hasil Belajar IPA Siswa Kelas IV SDN 07 Salule Mamuju Utara. Jurnal Universitas Tadulako, 3(2) 594-614.

Nurseto, T. (2011). Membuat Media Pembelajaran yang Menarik. JurnalEkonomi, 8(1) 287-298. 